\title{
Geospatial Water Quality Analysis of Downstream of Tamiraparani River
}

- Tamilnadu

DOI:10.36909/jer.ACMM.16329

\author{
D. Justus Reymond, Karuppasamy Sudalaimuthu*
}

\begin{abstract}
Department of Civil Engineering, SRM Institute of Science and Technology, SRM Nagar, Kattankulathur - 603203, Kanchipuram, TN, India

*E-mail: karuppas@ srmist.edu.in
\end{abstract}

\begin{abstract}
A physicochemical analysis of River Tamiraparani was carried out to determine critical environmental issues using GIS mapping techniques. A large proportion of water is used for power generation and intense agricultural activities, mostly paddy is grown in the river banks. It is the only drinking water source for the entire Tirunelveli. The present study aimed at application of GIS techniques to understand the spatial distribution pattern of important water quality parameters with ArcMap 10.2.1. Water samples were collected and analysed following standard methods from 11 different locations covering the stretch from Authoor to Punnakayal during November 2020. A comprehensive physicochemical assessment of 10 indicator parameters namely conductivity, alkalinity, hardness, calcium, magnesium, chloride, sulphate, Total Dissolved Solids (TDS), sodium and potassium were carried out. The results showed that all the parameter apart from alkalinity exceeded the permissible limits specified by World Health Organization (WHO) and Bureau of Indian Standards (BIS) 2012. It was found that the first three locations (Authoor, Mukkani and Sertnthapoomangalam) met the specified drinking water standards because there is no such sea water intrusion happened. It is found that Kailasapuram that is the 4 sampling location onwards the concentration of TDS varies in the range of 19,600-27,650 mg/l, conductivity is in the range of $40,000-48,000 \mu \mathrm{s} / \mathrm{cm}$, hardness is in the range of $1,500-4,200 \mathrm{mg} / \mathrm{l}$, chloride is in the range of $12,000-17,000 \mathrm{mg} / \mathrm{l}$, calcium varies in the range of $300-435 \mathrm{mg} / \mathrm{l}$, magnesium is in the range of $800-1100 \mathrm{mg} / \mathrm{l}$, sulphate is in the range of $1300-1600 \mathrm{mg} / \mathrm{l}$, sodium is in the range of $6000-9,000 \mathrm{mg} / \mathrm{l}$ and potassium varies in the range of 450-600 mg/l. This could be due to pollution loads entering from sewage discharge, washing of clothes, bathing and sea
\end{abstract}


water intrusion. The study is mandatory for the decision makers and public for reduce the contamination levels in the study area, since it is a major source of water for domestic and agricultural activities of surrounding.

Keywords- Tamiraparani river, Surface water quality, Physicochemical analysis, GIS.

\section{INTRODUCTION}

Water is the very common and essential for all life. It has played a vital role in determining the course of the history of the earth. It is the most potent and the most wonderful thing on the face of our earth. The preservation and utilisation of water is thus essential for human welfare. Water quality analysis is the basic method used to comprehend the variation of water quality of polluted water bodies and hence protect and preserve them [1]. In developing countries like India, where almost $70 \%$ of the surface water is contaminated because of discharge of domestic and industrial wastewater, thus water quality assessment become an important issue for satisfying the basic needs of the people throughout their lives [2].

This situation has been emerging as a delicate and life-threatening problem in several countries. Therefore, many researches have been carried out to address this issue [3-5]. In coastal regions, salt water intrusion into fresh water has become a severe consequence because of unplanned exploitation of water resources [6]. Contamination of water bodies also increase the risk of waterborne diseases. Almost $80 \%$ of all the infections in human beings are waterborne. In India, access to safe drinking water continues to be a crucial requirement, because much of the population entirely depends on untreated surface or groundwater [7]. Therefore, it is very much essential to determine the variations in river water quality and availability to come up with contaminated regions for sustainable management of water resources [8].

GIS is an information system used to input, store, recover, manipulate, and analyse spatial and non-spatial data. It is avaluable tool to analyse spatial data and derive useful outputs and modelling. It can be effectively used to for assessing water quality, checking water availability and developing solutions for water resources problems and managing water resources. The overlay GIS mapping techniques are widely used for pollution studies. There are few literatures available for river and groundwater water quality mapping and analysis using GIS techniques [9-11]. 
The key aim of the present study is to analysis the physicochemical parameters and represents changes in these parameters using GIS mapping techniques and to find the critical zones of the river in need of immediate action. The study begins with collecting the samples as per the standards, subsequently laboratory analysis carry out by means of $\mathrm{pH}$, Conductivity, Turbidity meter for determining the Physio-chemical parameters. Besides, GIS techniques helps to prepare and analyse the spatial distribution of water quality contamination through Inverse Distance Weighted (IDW) methods.

\section{STUDY AREA}

The River Tamiraparani is the only perennial river in Tirunelveli, Tamil Nadu. It originates on the eastern slopes of the Western Ghats at an altitude of $2000 \mathrm{~m}$, travels about 125-128 km in the hills and plains, covering a total area of $5369 \mathrm{~km}^{2}$. The study area lies between $78^{\circ} 4^{\prime}$ $78^{\circ} 7^{\prime} \mathrm{E}$ longitudes and $8^{\circ} 37^{\prime}-8^{\circ} 38^{\prime} \mathrm{N}$ latitudes (Figure 1). The variation in annual rainfall and temperature is found to be between $1,000-1100 \mathrm{~mm}$ and 20 to $38{ }^{\circ} \mathrm{C}$ respectively [12].

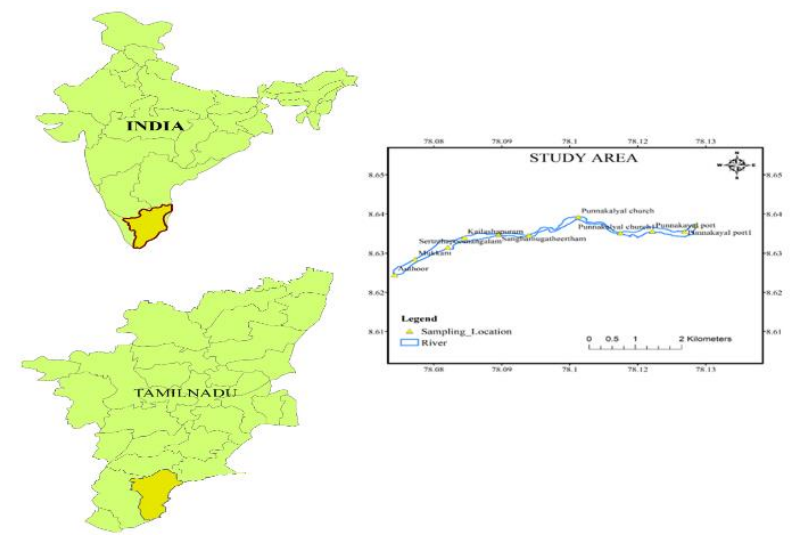

Figure 1 The study area map with sampling locations

The elevated areas are covered with moderately dense tropical wet evergreen and tropical moist deciduous forests, following dendritic to sub-dendritic drainage pattern [13]. The major tributaries of the River are: Servalar, Manimuthar, Gadananathi, Chittar, Pachaiyar, Karaiyar and Ramanathi. The upper reaches of the bed of the river is made up of igneous and metamorphic rocks and the middle and the lower reaches are sandy in nature. The river basin has extensive alluvium deposition which is used for cultivation. The major soil types found in the basin are red soils and the mixture of the red and black clay soils [12-13]. 
A large proportion of water is used for power generation and intense agricultural activities, mostly paddy is grown in the river banks and is the only drinking water source for the entire district. The causes of the river pollution in the area are: a large amount of wastewater from residences, industries, illegal sand mining, illegal encroachments, religious practices like bathing and sea water intrusion.

\section{MATERIALS AND METHODOLOGY}

The study area Thamiraparani River was delineated from Cartosat-1 orthophotos, which is used as source for selecting the sampling locations. According to the base map, samples were collected in the month of November 2020 from 11 different sampling sites as depicted in the (Figure 1). The latitudes and longitudes of the sampling locations were noted down using the GPS. The water samples were collected, transported, preserved and analysed as per the standard methods prescribed in APHA [14]. Furthermore; samples incubated for laboratory analysis to determine the Physicochemical parameters namely $\mathrm{pH}$, turbidity, conductivity, alkalinity, hardness, Calcium (Ca), Magnesium $(\mathrm{Mg})$, Chloride $(\mathrm{Cl})$, Sulphate $\left(\mathrm{SO}_{4}\right)$, Total Dissolved Solids (TDS), Sodium (Na) and Potassium (K). The measurement of pH, TDS and EC was done using portable sensors, in addition Titrimetric methods were used to analyse alkalinity, hardness, chloride, calcium and magnesium. The flame photometer was used to determine sodium and potassium [15 -16]. Database was created for the analysed samples with their corresponding sampling locations using GIS software. The sampling station name with their corresponding latitude and longitude are shown in the Table 1.

Table 1 Geographical positions of the sampling sites of Tamirabarani river.

\begin{tabular}{|c|l|c|c|}
\hline Sl.No & \multicolumn{1}{|c|}{ Sampling station } & Latitude & Longitude \\
\hline 1 & Authoor & 8.626117 & 78.06862 \\
\hline 2 & Mukkani & 8.630392 & 78.07262 \\
\hline 3 & Saernthapoomangalam 1 & 8.633611 & 78.07896 \\
\hline 4 & Kailasapuram & 8.636278 & 78.08219 \\
\hline 5 & Sangamugatheertham & 8.636725 & 78.08886 \\
\hline 6 & Saernthapoomangalam 2 & 8.636928 & 78.09473 \\
\hline
\end{tabular}




\begin{tabular}{|c|l|c|c|}
\hline 7 & Punnakayal Church part 1 & 8.641475 & 78.10434 \\
\hline 8 & Punnakayal Church part 2 & 8.637558 & 78.1125 \\
\hline 9 & Punnakayal Port 1 & 8.637706 & 78.11869 \\
\hline 10 & Punnakayal Port 2 & 8.637903 & 78.12494 \\
\hline 11 & Estuary Mouth & 8.639567 & 78.12711 \\
\hline
\end{tabular}

The following figure 2 represents the steps which is followed for this work. It includes sample collection, testing, comparison, mapping, understand the pollution level of tamiraparani river and reason for the same.

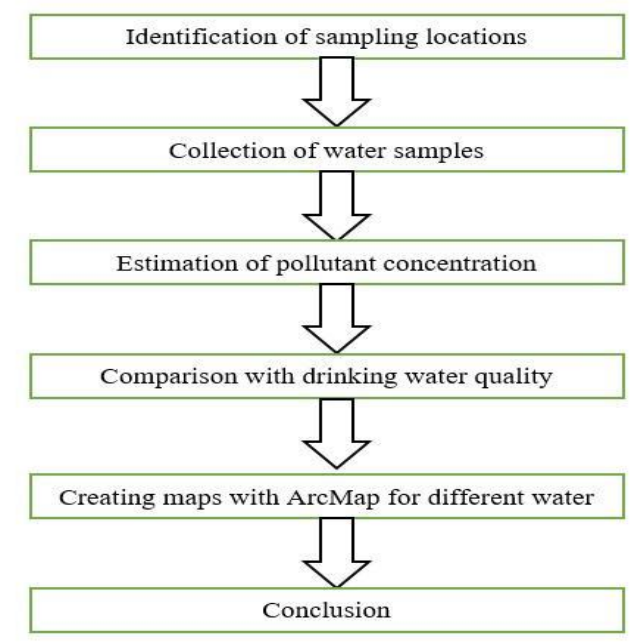

Figure 2 Methodology flow chart

\section{RESULTS AND DISCUSSION}

Waste water from residences and industries find its way directly to the river water making it unfit for human use. In addition, Sea water intrusion is also a major reason for making this water unsuitable for human consumption. The key aim of the study is to analysis the physicochemical parameters and represents changes in these parameters using Geospatial techniques also to find the critical zones of the river in demands immediate action [17]. The water quality sampling places and the results obtained from water quality analysis are shown in Table 2. 
Table 2 Physio-chemical characteristics of Thamiraparani River at sampling stations

\begin{tabular}{|c|c|c|c|c|c|c|c|c|c|c|}
\hline $\begin{array}{c}\text { S. } \\
\text { No. }\end{array}$ & $\begin{array}{c}\text { TDS } \\
(\mathbf{m g} / \mathbf{l})\end{array}$ & $\begin{array}{c}\text { EC } \\
(\boldsymbol{\mu} \mathbf{s} / \mathbf{c m})\end{array}$ & $\begin{array}{c}\text { Alkalinity } \\
(\mathbf{m g} / \mathbf{l})\end{array}$ & $\begin{array}{c}\text { Hardness } \\
(\mathbf{m g} / \mathbf{l})\end{array}$ & $\begin{array}{c}\text { Chloride } \\
(\mathbf{m g} / \mathbf{l})\end{array}$ & $\begin{array}{c}\mathbf{C a} \\
(\mathbf{m g} / \mathbf{l})\end{array}$ & $\begin{array}{c}\text { Mg } \\
(\mathbf{m g} / \mathbf{l})\end{array}$ & $\begin{array}{c}\text { Sulphate } \\
(\mathbf{m g} / \mathbf{l})\end{array}$ & $\begin{array}{c}\text { Na } \\
(\mathbf{m g} / \mathbf{l})\end{array}$ & $\begin{array}{c}\text { K } \\
(\mathbf{m g} / \mathbf{l})\end{array}$ \\
\hline 1 & 351 & 615 & 113 & 104 & 112 & 28.32 & 26 & 58 & 50 & 4 \\
\hline 2 & 403 & 792 & 96 & 109 & 156.27 & 24.84 & 21.2 & 64 & 78 & 6 \\
\hline 3 & 493 & 856 & 91 & 115 & 161.2 & 25 & 27 & 66 & 75 & 7 \\
\hline 4 & 21054 & 42384 & 84 & 1682 & 12034 & 285.61 & 793 & 1329 & 6106 & 451 \\
\hline 5 & 20812 & 40327 & 118 & 1975 & 13132 & 372 & 811 & 1284 & 6892 & 469 \\
\hline 6 & 19588 & 39026 & 125 & 2387 & 12454 & 364 & 860 & 1502 & 6321 & 452 \\
\hline 7 & 26031 & 44580 & 137 & 2539 & 13611.89 & 431 & 970.4 & 1632.27 & 7958 & 517 \\
\hline 8 & 26545 & 45327 & 146 & 3006 & 14834 & 418 & 1012 & 1608 & 8107 & 528 \\
\hline 9 & 25672 & 45678 & 154 & 3598 & 15761 & 404 & 1104 & 1576 & 8341 & 595 \\
\hline 10 & 27035 & 46017 & 169 & 3619 & 16679 & 369 & 1093 & 1537 & 8503 & 608 \\
\hline 11 & 27643 & 48028 & 178 & 4190 & 16854.62 & 435.64 & 1126.2 & 1624.1 & 8729 & 616 \\
\hline
\end{tabular}

The fitness of river water for drinking, domestic and agricultural usage was evaluated by comparing the results with those prescribed in the standards. BIS and WHO standards for the drinking water is depicted in the Table 3. 
Table 3 The standards for drinking water laid down by BIS and WHO

\begin{tabular}{|c|c|c|c|c|c|}
\hline $\begin{array}{l}\text { Sl. } \\
\text { No. }\end{array}$ & $\begin{array}{c}\text { Parameter } \\
\text { (mg/L) }\end{array}$ & $\begin{array}{c}\text { Acceptable } \\
\text { limit } \\
\text { (IS10500:2012) }\end{array}$ & $\begin{array}{l}\text { Sl. } \\
\text { No. }\end{array}$ & $\begin{array}{c}\text { Parameter } \\
(\mathrm{mg} / \mathrm{L})\end{array}$ & $\begin{array}{l}\text { Acceptable limit } \\
\text { (IS10500:2012) }\end{array}$ \\
\hline 1 & TDS & 500 & 5 & Magnesium & 30 \\
\hline 2 & Alkalinity & 200 & 6 & Sulphate & 200 \\
\hline 3 & Total Hardness & 200 & 7 & Calcium & 75 \\
\hline 4 & Chloride & 250 & 8 & Sodium & 200 (WHO) \\
\hline
\end{tabular}

\section{Physicochemical parameters}

\section{Alkalinity}

The major chemical species to constitute alkalinity in the water environment are dissolved carbon dioxide, bicarbonate, carbonate, hydrogen and hydroxyl ions [18]. The BIS standards for total alkalinity as $\mathrm{CaCO}_{3}$ is $200 \mathrm{mg} / \mathrm{l}$. It is understood from the figure 3 that highest level of alkalinity $178 \mathrm{mg} / \mathrm{l}$ is shown in the Estuary mouth whereas the lowest alkalinity observed as $84 \mathrm{mg} / \mathrm{l}$ from Kailasapuram.

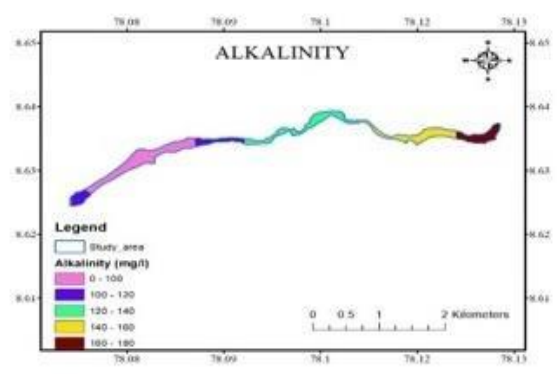

Figure 3 Variation of alkalinity along Tamiraparani River

\section{Conductivity}

The major chemical species to constitute conductivity in the water environment are dissolved ions. The natural compounds do not conduct electric current and for this reason do not impart conductivity [24]. Figure 4 clearly show that there is a significant increase in conductivity values from sampling location 4 onwards. The maximum value of $48028 \mu \mathrm{S} / \mathrm{cm}$ is observed 
at Punnakayal Port. This could be due to sea water intrusion. The other sources could be industrial and domestic waste water entering the river. Water with conductivity values above $500 \mu \mathrm{S} / \mathrm{cm}$ is not appropriate for drinking water purposes as per BIS standards.

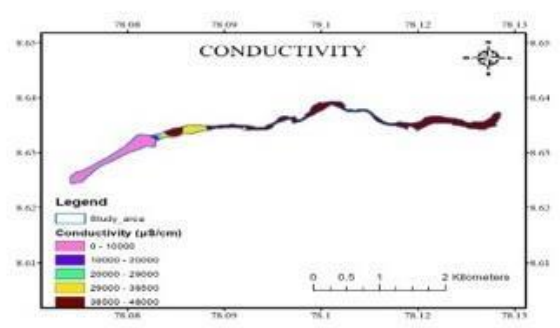

Figure 4 Variation of conductivity along Tamiraparani River

\section{TDS}

The occurrence of TDS in water affects its palate, clogs gills of the fish, increases its temperature and blocks photosynthetic activities of underwater plants [32]. The drinking water is considered excellent if its TDS value is less than $300 \mathrm{mg} / \mathrm{l}$, good if it varies between $300-600 \mathrm{mg} / \mathrm{l}$, fair if it varies between $600-900 \mathrm{mg} / \mathrm{l}$, poor if it varies between 900 $1,200 \mathrm{mg} / \mathrm{l}$ and unacceptable if it is more than $1,200 \mathrm{mg} / \mathrm{l}$.Figure 5 shows the variation in total dissolved solids concentration of the analysed samples. The results show that the TDS values of the samples collected from locations Authoor, Mukkani and Sertnthapoomangalam are within the permissible limits by BIS. The highest TDS concentration of $27643 \mathrm{mg} / \mathrm{l}$ was observed at Punnakayal Port.

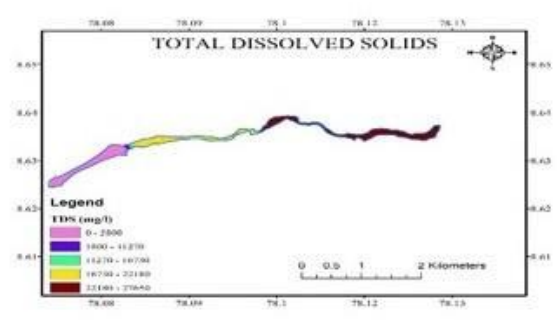

Figure 5 Variation of TDS along Tamiraparani River 


\section{Total Hardness}

The dissolution of the metal ions like calcium and magnesium makes surface water sources hard. The hardness of the collected samples is found to be in the range of $100-4200 \mathrm{mg} / \mathrm{l}$ as depicted in figure 6 . The hardness value of the first three locations was found to be varying between 100-115 mg/l. Water with hardness < $100 \mathrm{mg} / \mathrm{l}$ has a low buffering capacity and can corrode water pipes. Whereas, the rest of the locations have very high hardness values. Water with hardness $>200 \mathrm{mg} / \mathrm{l}$ cause scale formation in the water treatment facilities [31].

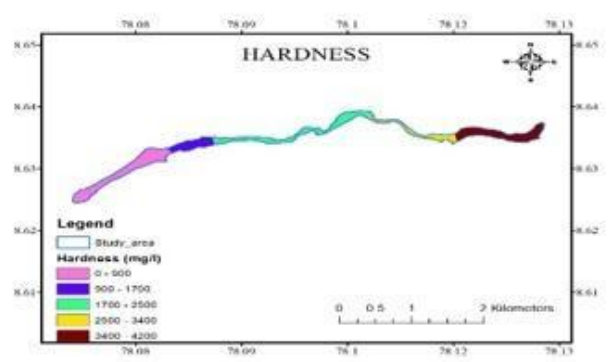

Figure 6 Variation of total hardness along Tamiraparani River

\section{Calcium}

Calcium often is the most abundant cation in river water. Calcium leads to poor lathering, deterioration of clothes, incrustation in pipes and scale formation [38]. The results obtained from analysis for calciumin the present study showed that the values were well within the standard limits for first three locations namely Authoor, Mukkani and Sertnthapoomangalam. The concentration of calcium for rest of the locations did not meet the prescribed standards. From the results and figure 7 the calcium concentration in the samples of study area varied in the range of $25-435.64 \mathrm{mg} / \mathrm{l}$.

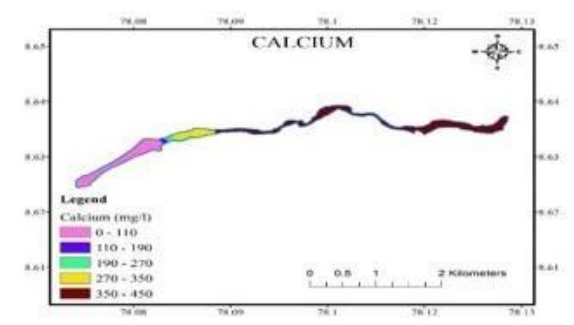

Figure 7 Variation of calcium along Tamiraparani River 


\section{Magnesium}

The analysis results of magnesium carried out in the present study showed that the values were well within the standard limits for first three locations namely Authoor, Mukkani and Sertnthapoomangalam. The concentration of magnesium at remaining locations did not meet the prescribed standards. This could be due to fertilizers and waste entering from chemical industries [23]. From figure 8 the concentration of the magnesium of the measured samples varied between $20-1126.2 \mathrm{mg} / \mathrm{l}$.

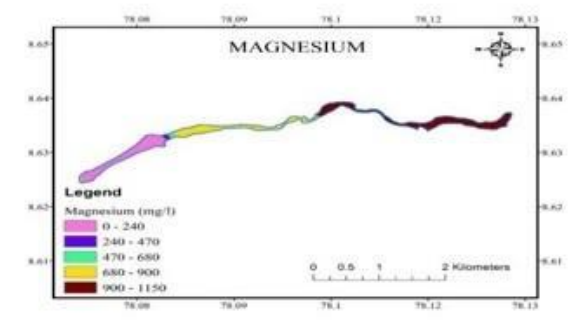

Figure 8 Variation of magnesium along Tamiraparani River

\section{Sodium}

Sodium metal is not found in free form in nature because of its high reactivity.It has an average taste threshold of about $200 \mathrm{mg} / \mathrm{l}$ at room temperature. It can have adverse health effects on humans, especially people with high blood pressure [25]. The WHO standards recommended for sodium as $200 \mathrm{mg} / \mathrm{l}$. The concentration of sodium in water samples analysed range between 50 and $8729 \mathrm{mg} / \mathrm{l}$, figure9. It can find its way in water from fertilizers and untreated sewage waste.

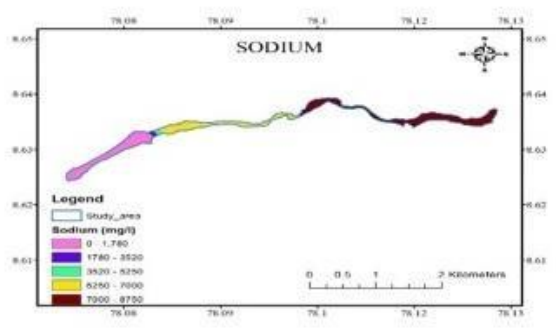

Figure 9 Variation of sodium along Tamiraparani River 


\section{Chlorides}

Sodium, potassium, calcium and magnesium chlorides are commonly found in natural water. The average taste threshold of sodium, potassium and calcium chloride lies between 200 to $300 \mathrm{mg} / \mathrm{l}$ at room temperature. The chloride anion taste threshold depends on the related cations [27]. Based on taste threshold criteria, The BIS standards for chlorides as $1000 \mathrm{mg} / \mathrm{l}$ for drinking water. The concentration of chlorides obtained in water samples between 112 $16854.62 \mathrm{mg} / \mathrm{l}$, figure 10 . The high concentrations could be due to salt water intrusion.

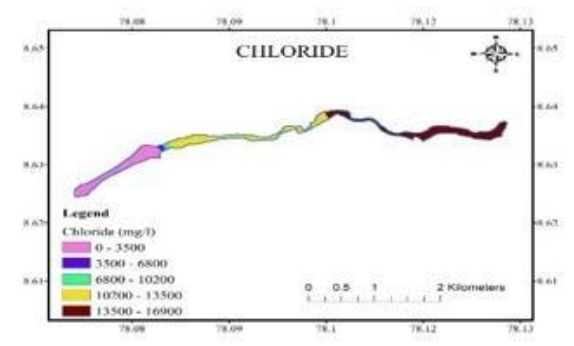

Figure 10 Variation of chloride along Tamiraparani River

\section{Sulphates}

Sulphate is the most common form of sulphur present in well aerated natural waters. The taste of the drinking water changes noticeably in the presence of the sulphates and if present in high levels can causeadverse effect in humans [23]. As per BIS the desirable limit for sulphate in drinking water as $200 \mathrm{mg} / \mathrm{l}$. Figure 11 shows the variation in sulphate concentration of the water samples analysed for the present study, higher concentration in $7^{\text {th }}$ location of $1632.27 \mathrm{mg} / \mathrm{l}$. It is observed that it is not within the acceptable limits prescribed by BIS for drinking water.

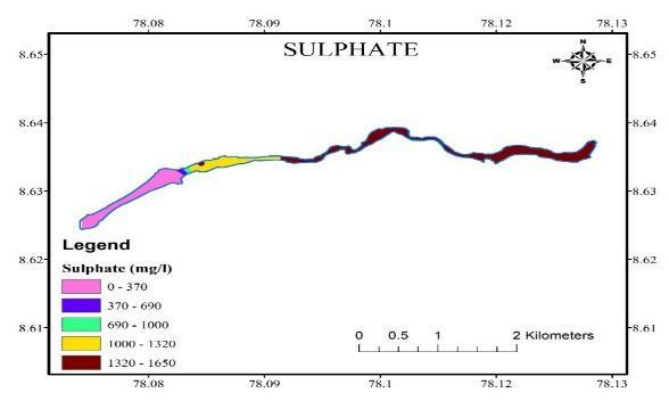

Figure 11 Variation of sulphate along Tamiraparani River 


\section{Potassium}

Potassium is avital element needed for proper functioning of human body and could be a concern if found in high levels in drinking water [22]. The concentration of potassium in water samples between $4-616 \mathrm{mg} / \mathrm{l}$ shown in figure 12. In drinking water, $10 \mathrm{mg} / \mathrm{l}$ of potassium is permissible. The major reason for high concentration in water sample is due to presence of fertilizers [24].

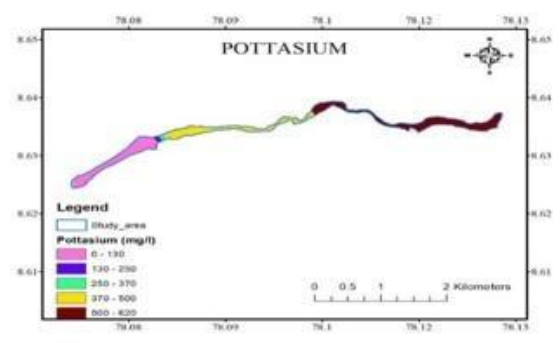

Figure 12 Variation of potassium along Tamiraparani River

\section{Conclusions}

GIS based mapping techniques were used to analyse the variation and distribution of physicochemical characteristics of important water quality parameters at Thamiraparani River. The study revealed that except alkalinity all the parameters were exceeded the prescribed limits specified by BIS. Particularly the last location which is near to sea has higher amount of TDS $27643 \mathrm{mg} / \mathrm{l}$ and conductivity as $48028 \mu \mathrm{s} / \mathrm{cm}$ due to sea water intrusion. Besides, GIS techniques spatially represented the level of contamination with reference to the analyzed samples. It came to know from the study that are many parameters are influences the contamination in which sea water intrusion, anthropogenic activities and direct discharge of sewage in to the river from the industrial activities are the major influential parameters. Thus, leads to reduce the suitability for drinking, domestic and irrigation purposes. Consequently, the investigation prescribes to distinguish and limit the both point and non-point source contamination by methods for geospatial techniques. In the event that legitimate measures are taken for the treatment of sewage before release and limitations are put on different anthropogenic exercises in upstream and downstream, the estuary would stay sound over the long haul. This examination encourages us to comprehend the nature of the water just as to create judicious management practices to safeguard the water resources. 


\section{REFERENCES}

Atefeh Mir, et al, 2017. Spatial monitoring and zoning water quality of Sistan River in the wet and dry years using GIS and geostatistics. Computers and Electronics in Agriculture, vol.135, pp. 38-50.

Ujjania, N.C et al, 2015. Water quality and pollution status of Tapi river, Gujarat, India. International Journal of Pure Applied Zoology, vol.1, pp.261-266.

Rui Xia, et al, 2015. Integrated water quality assessment of the Huai River Basin in China. Journal of Hydrology and Engineering, vol. 20, pp. 05014018-1-8.

Xiong Yang, et al, 2020. Water pollution characteristics and analysis of Chaohu Lake basin by using different assessment methods. Environmental Science and Pollution Research.

Andreea-Mihaela Dunca, 2018. Water pollution and water quality assessment of major transboundary rivers from Banat (Romania). Journal of Chemistry, pp. 1-8.

Thadchayini, T. et al, 2005. An economic evaluation of drip irrigation project for banana cultivation in Jaffna district," In: Water Resources Research in Sri Lanka, Proceedings of the Symposium of the Water Professionals Day, Peradeniya, Sri Lanka, Galagedara, L.G., Ed.; Postgraduate Institute of Agriculture: Peradeniya, Sri Lanka; pp. 111-126.

Palanisamy, P.N et al, 2007. Assessment of ground water quality in and around Gobichettipalayam town Erode District, Tamil Nadu, India. E-Journal of Chemistry, vol. 4, pp. 434-439.

Puri, P.J et al, 2015. Application of water quality index (WQI) for the assessment of surface water quality (Ambazari Lake). European Journal of Experimental Biology, vol. 5, pp. 3752,

Sener, S. et al, 2017. Evaluation of water quality using water quality index (WQI) method and GIS in Aksu River (SW-Turkey). Science of Total Environment, 584-585, pp. 131-144.

Srivastava, P.K et al, 2011. Characterizing monsoonal variation on water quality index of River Mahi in India using Geographical Information System. Water Quality, Exposure and Health, vol. 2, pp. 193-203.

Srivastava, P.K et al, 2008. Groundwater quality assessment and its relation to land use/land cover using remote sensing and GIS," In: Proceedings of International Groundwater 
conference on groundwater use-efficiency and sustainability: groundwater and drinking water issues, Jaipur, India.

Ravichandran, S. 2003. Hydrological influences on the water quality trends in Tamiraparani Basin, South India. Environmental Monitoring and Assessment, vol. 87, pp. 293-309.

Magesh, N.S et al, 2014. GIS model-based morphometric evaluation of Tamiraparani subbasin, Tirunelveli district, Tamil Nadu, India. Arabian Journal of Geosciences, vol. 7, pp. 131-141.

Justus Reymond, D., Sudarsan, J.S., Annadurai, R. \& Nithiyanantham, R. 2018. Groundwater quality around municipal solid waste dumpin Tiruchirappalli (South India). International Journal of Environmental Science and Technology.

Bureau of Indian Standards (BIS), Drinking water specifications, IS 10500: 2012, 2012.

WHO, Guidelines for drinking-water quality, Geneva, Switzerland, 2012.

Ghosh, J.K., et al, 2020. Applications of Geometics in Civil Engineering. Springer Science and Business Media LLC.

George, L.B., et al, 1985. Rates, Constants and Kinetics Formulations in Surface Water Quality Modeling, published by Tetra Tech, Incorporated, under the sponsorship of the USEPA.

Sajal Singh, et al, 2016. Water quality index development for groundwater quality assessment of Greater Noida sub-basin, Uttar Pradesh, India," Cogent Engineering, vol. 3, pp. $1-17$.

Metcalf \& Eddy, 2003. Wastewater Engineering: Treatment and Reuse," Fourth Edition, McGraw Hill Companies.

Justus Reymond, D., Karuppasamy Sudalaimuthu, \& Sakthi Maheswaran, P. 2020. Analysis of Organic Pollutant and Coliform in Thamiraparani River with Artificial Neural Networks” AIP Conf. Proc. 2277, 180001-1-180001-8; 2020.

Girija TR, et al. 2007. Water quality assessment of an untreated effluent impacted urban stream: the Bharalu Tributary of the Brahmaputra River, India. Environmental Monitoring and Assessment ,130: 221-236. 
Ravindra K, et al. 2003. Seasonal variations in physico-chemical characteristics of River Yamuna in Haryana and its ecological best-designated use. Journal of Environmental Monitoring, 5: 419-426.

Gaillardet, J., Dupre, B. Alle`gre, C.J. \& Ne'grel, P. 1997. Chemical and physical denudation in the Amazon river basin. Chem Geol 142:141-173.

Gaur, V.K., Gupta, S.K., Pandey, S.D., Gopal, K. \& Misra, V. 2005. Distribution of heavy metals in sediment and water of river Gomti. Environ Monitor Assess 102:1-3.

Gibbs, R.J. 1970. Mechanism controlling world water chemistry. Science 17:1088-1090.

Guler, C., Thyne, G., McCray, J.E. \& Turner, A.K. 2002. Evaluation and graphical and multivariate statistical methods for assification of water chemistry data. Hydrogeol J 10:455474.

Brahabhatt, V.S., Dalwadi, G.B., Chhabra, S.B., Ray, S.S. and Dadhwal, V.K. 2000. Landuse/landcover changes mapping in Mahi canal command area, Gujarat, using multitemporal satellite data. Journal of Indian Society of Remote Sensing, 28:221-32.

Shamsudheen, M., Dasog, G.S. and Tejaswini, N.B. 2005. Land use/Land cover mapping in the coastal area of North Karnataka using remote sensing data. Journal of the Indian Society of Remote Sensing,33:253-7.

Mayilvaganan, M.K., Mohana, P. \& Naidu, K.B. 2011. Delineating ground water potential zones in Turinjapuram watershed using geospatial techniques. Indian Journal of Science and Technology.4(11):1470-6, 2011.

Ratnaparkhi, N.S. 2014. National Remote Sensing Centre NRSC. Remote Sensing Application in Land Use Land Cover Classification System.5(7):1-5.

Elmanama, A.A., et al. 2006. Seasonal and spatial variation in the monitoring parameters of Gaza Beach during 2002-2003. Environmental Research, 101(1):25-33.

APHA, Standard Methods for Examination of Water and Wastewater, 20th ed., Washington, DC, 1999.

Oliver Paul Nayagam, J., Justus Reymond, D., Kabilashasundari, S., Naveen Karthik, B. \& Ramesh, B. 2019. Environmental Assessment of Marine and Estuarine Waters along 
the Coast of Thoothukudi City. International Journal of Engineering and Advanced Technology, Volume-8 Issue-4.

Padmanaban, R., Karuppasamy, S. \& Narayanan, R. 2018. Assessment of pollutant level and forecasting water pollution of Chennai coastal, TamilNadu using R. Indian Journal of Geo-Marine Sciences 47(7), pp. 1420-1429.

Sheebha Malar, O.V., Kokila, P. \& Isac Sobana Raj, C. 2018. Physico chemical parameters of water of some selected areas of Tamirabarani river, Tirunelveli, Tamilnadu. International Journal of Scientific Research and Management (IJSRM) Vol06, Issue 10, PP 111-117.

Kumarasamy, P., Hans-Uwe Dahms., Hyoung-Joo Jeon., Rajendran, A. \& Arthur James, R. 2014. Irrigation water quality assessment — an example from the Tamiraparani river, Southern India. Arab J Geosci, 7:5209-5220.

Sidhardhan, S., Adish Kumar, S. \& Roger Merin, R. Current Water Quality Status of River Thamirabarani. SSRG International Journal of civil Engineering, pp 411-415. 